\title{
ANALISIS KUALITAS PELAYANAN TERHADAP KEPUASAN MAHASISWA PROGRAM STUDI PENDIDIKAN GURU SEKOLAH DASAR
}

\author{
Hendro Widodo \\ PGSD FKIP UAD Yogyakarta \\ Email: hendro804@yahoo.com
}

\begin{abstract}
This study aims to determine: 1) the quality of service UAD Yogyakarta PGSD Studies Program; 2) Study Program student satisfaction PGSD UAD; and 3) the influence of service quality on student satisfaction UAD PGSD Studies Program. The study design used is a causal associative design. The research population is all students Prodi researchers PGSD is still active in the academic year 2013/2014, amounting to 688 students. Samples were taken at $25 \%$ or as many as 187 students. Data were analyzed using multiple linear regression analysis. The study concluded that: 1 ) the quality of service Prodi PGSD UAD is quite good; 2) students feel quite satisfied with the services provided by Prodi PGSD UAD; and 3) there are two dimensions that have a significant effect on student satisfaction UAD PGSD Studies Program, of the five dimensions of service quality that is tangible dimension and the dimension of assurance, while the dimensions of reliability, responsiveness and empathy dimensions do not have a significant effect on student satisfaction. However, simultaneous dimensions of quality have a significant influence on student satisfaction.
\end{abstract}

Keywords: Quality Service, Student Satisfaction

\begin{abstract}
ABSTRAK
Penelitian ini bertujuan untuk mengetahui: 1) kualitas pelayanan Program Studi PGSD UAD Yogyakarta; 2) kepuasan mahasiswa Program Studi PGSD UAD; dan 3) pengaruh kualitas pelayanan terhadap kepuasan mahasiswa Program Studi PGSD UAD. Desain penelitian yang digunakan adalah desain asosiatif kausal. Populasi penelitian yang digunakan peneliti adalah seluruh mahasiswa Prodi PGSD yang masih aktif pada tahun akademik 2013/2014 yang berjumlah 688 mahasiswa. Sampel penelitian diambil sebesar 25\% atau sebanyak 187 mahasiswa. Teknik analisis data menggunakan analisis regresi linier berganda. Hasil penelitian menyimpulkan bahwa: 1) kualitas pelayanan Prodi PGSD UAD tergolong cukup baik; 2) mahasiswa merasa cukup puas dengan pelayanan yang diberikan oleh Prodi PGSD UAD; dan 3) terdapat dua dimensi yang mempunyai pengaruh signifikan terhadap kepuasan mahasiswa Program Studi PGSD UAD, dari lima dimensi kualitas pelayanan yaitu dimensi tangible dan dimensi assurance, sedangkan dimensi reliability, responsiveness dan dimensi emphaty tidak mempunyai pengaruh signifikan terhadap kepuasan mahasiswa. Namun demikian, secara simultan dimensi kualitas memberikan pengaruh yang signifikan terhadap kepuasan mahasiswa.

Kata Kunci: Kualitas Pelayanan, Kepuasan Mahasiswa
\end{abstract}




\section{Pendahuluan}

Iklim kompetisi dalam dunia pendidikan tinggi Indonesia saat ini semakin terasa. Di sisi lain perubahan lingkungan yang demikian pesat semakin mendukung kompetisi yang sedang terjadi saat ini, baik kompetisi yang bersifat loal, regional, global. Perguruan Tinggi di Indonesia baik yang berstatus negeri maupun swasta tidak hanya bersaing dengan perguruan tinggi local, tetapi juga berbagai lembaga perguruan tinggi di tingkat nasional bahkan internasional. Berdasarkan data statistik Pendidikan Perguruan Tinggi Kemendikbud tahun 2013 menyebutkan Universitas berjumlah 433, Institut 50, Sekolah Tinggi 1223, Akademi 951 dan Politeknik 148. Demikian pula terjadi kompetisi dalam perguruan tinggi persyarikatan Muhammadiyah yang saat ini sudah mencapai 172 perguruan tinggi dan $40 \mathrm{di}$ antaranya adalah kategori Universitas.

Meningkatnya kuantitas perguruan tinggi ini menuntut masing-masing lembaga pendidikan harus memperhatikan mutu pendidikan dan kelembagaan sehingga mampu serta unggul dalam persaingan tersebut. Di sisi lain perguruan tinggi dituntut untuk menggali dan meningkatkan segala aspek pelayanan yang prima akan berimplikasi pada peningkatan citra perguruan tinggi dan sebaliknya pelayanan yang buruk akan menurunkan citra perguruan tinggi itu sendiri.

Kualitas merupakan inti dari kesinambungan eksistensi hidup suatu institusi. Gerakan revolusi dalam meningkatkan mutu terpadu menjadi kebutuhan sekaligus tuntutan yang tidak dapat diabaikan jika institusi tersebut ingin tetap eksis dan berkembang. Kompetisi yang semakin ketat antar institusi pendidikan (Perguruan Tinggi) semakin menuntut suatu perguruan tinggi untuk selalu memanjakan pelanggannya (mahasiswa) dengan pelayanan yang baik, karena mahasiswa akan mencari perguruan tinggi yang memberikan pelayanan yang terbaik baginya.

Kualitas suatu perguruan tinggi sangat ditentukan oleh mutu pelayanan yang diberikan, dimana pelayanan yang bermutu dapat diindetifikasi melalui kepuasan pelanggan dalam hal ini adalah mahasiswa. Bagi sebuah perguruan tinggi kepuasan layanan lebih diorientasikan kepada mahasiswa karena mahasiswa merupakan pelanggan primer dari perguruan tinggi. Perguruan tinggi sebagai industri jasa harus terus memikirkan pentingnya pelayanan pelanggan secara lebih matang, kerena kini semakin disadari bahwa pelayaan dan kepuasaan pelanggan merupakan aspek vital dalam rangka bertahan dalam bisnis 
dan memenagkan persaingan (Tjiptono, 2004: 145).

Layanan yang berkualitas akan memberikan kepuasan kepada mahasiswa. Kepuasan mahasiswa ditujukan dengan adanya keloyalan mahasiswa pada perguruan tinggi dan mahasiswa akan menceritakan mengenai layanan akademik yang memuaskan kepada orang lain. Kepuasan menurut Pakar Day (Tjiptono, 2004: 146) menyatakan bahwa kepuasan atau ketidakpuasan adalah respon pelanggan terhadap evaluasi ketidaksesuaian/diskonfirmasi yang dirasakan antara harapan sebelumnya dan kinerja aktual produk yang diarasakan setelah pemakaiannya. Tingkat kepuasan mahasiswa terhadap jasa pelayanan pendidikan dapat diketahui dengan cara membandingkan anatara harapan dengan kenyataan yang mahasiswa rasakan.

Kepuasan mahasiswa akan tercapai apabila ada kesesuaian antara layanan yang diberikan kepada mahasiswa. Sebagaimana dikemukakan oleh Wadwa dan Radja (2006: 222) bahwa kepuasan mahasiswa akan layanan yang diterimanya dilihat dari kesesuaian anatara harapan dan kinerja layanan yang diterimanya. Berangkat dari konsep dasar kepuasan pelanggan, perguruan tinggi pada dasarnya adalah industry jasa yang memeberikan layanan atau jasa kependidikan yang tujuannya untuk memeberikan kepuasan pada pelanggannya (mahasiswa). Menurut Tilaar (202: 11) dewasa ini peeguruan tinggi dihadapkan pada tuntutan akan mutu dan akuntablitas atas jasa pendidikan yan diberikannya, sehingga layanan bermutu harus diberikan untuk memuaskan pelanggannya.

Parasuraman, Zeithaml, dan Berry (1985:41) mendefinisikan kualitas pelayanan sebagai suatu bentuk skap, berkaitan tetapi tidak sama dengan kepuasan, sebagai hasil dari perbandingan antara harapan dengan kinerja. Berdasarkan definisi ini, maka diharapkan dengan kualitas layanan yang baik dan professional akan timbul kepuasan pelanggan. Konsep kualitas pelayanan yang sangat popular adalah konsep SerQual yang dkembangkan oleh Parasuraman, Berry dan Zeithml (1988: 16). Pertama kali konsep dari dimensi kualitas pelayanan diformulasikan menjadi sepuluh dimensi, kemudian disederhanakan menjadi lima dimensi, yaitu : 1) tangible (bukti langsung) mencakup fasilitas fisik, perlengkapan, pegawai, dan sarana komunikasi; 2) reliability (reliabilitas), yaitu kemampuan memberikan pelayanan yang dijanjikan dengan segera, akurat, dan memuaskan; 3) responsiveness (daya tanggap), yaitu keinginan staf membantu para pelanggan dan memberikan layanan dengan tanggap; 
4) assurance (jaminan), mencakup pengetahuan, kompetensi, kesopanan, dan sifat dapat dpercaya yang dimiliki staf, bebas dari bahaya, resiko, atau keraguraguan; dan 5) empathy (empati), meliputi kemudahan dalam menjalin relasi, komunikasi yang baik, perhatian pribadi, dan pemahaman atas kebutuhan individu para pelanggan.

Adanya kualitas layanan yang baik dan professional di sebuah perguruan tinggi akan menimbulkan kepuasan pelanggan (mahasiswa) dan efeknya akan berpengaruh pada behavioral intentions (keinginan berperilaku dari mahasiswa tersebut). Behavioral intentions inilah yang akan menjelaskan apakah seseorang mahasiswa akan memberikan rekomendasi positif atau negatif kepada sesama mahasiswa atau calon mahasiswa yang ingin melanjutkan kuliah di Program Studi PGSD UAD. Jika pelayanan yang diberikan dapat memenuhi keinginan, harapan, dan kebutuhan mahasiswa, maka dapat dinilai pelayanan itu memuaskan, dan sebaliknya, jika pelayanan yang diberikan tidak dapat memenuhi keingnan, hararapan, dan kebutuhan mahasiswa, maka dapat disimpulkan pelayanan itu tidak memuaskan.

Kepuasan mahasiswa menjadi sangat penting karena akan membuat loyal kepada institusi, bersedia mempromosikan institusi tersebut kepada orang lain, meningkatkan animo masyarakat untuk melanjutkan pendidikan di institusi itu, menngkatkan bargaining position dari institusi, dan meningkatkan citra dari institusi tersebut. Selain itu mahasiswa juga akan mempromosikan layanan yang baik dari perguruan tinggi kepada calon mahasiswa yang lain sehingga akan meningkatkan jumlah mahasiswa yang kuliah di perguruan tinggi tersebut. Termasuk dalam kepuasan mahasiswa antara lain kurikulum yang sesuai dengan harapan mahasiswa, rancangan perkuliahan yang sesuai dengan harapan mahasiswa, penyajian materi dan evaluasi yang sesuai dengan harapan mahasiswa, sarana dan prasarana perkuliahan yang sesuai dengan harapan mahasiswa, laboratorium yang sesuai denagan harapan mahasiswa, dan pembimbingan yang sesuai dengan harapan mahasiswa.

Kepuasan mahasiswa merupakan misi yang harus diwujudkan apabila suatu lembaga pendidikan ingin diterima oleh masyarakat serta dapat terus eksis dan berkembang di tengah-tengah dukungan masyarakat. Bentuk pelayanan yang diterima oleh mahasiswa di perguruan tinggi dapat mencakup pelayanan kegiatan akademik, kemahasiswaan dan administrasi. Beberapa permasalahan kualitas pelayanan tehadap mahasiswa di Prodi PGSD UAD masih dipandang 
kurang. Berdasarkan hasil studi pendahuluan peneliti menunjukkan bahwa dengan kondisi staf Tata Usaha yang baru satu, untuk melayani mahasiswa yang kurang lebih 761 dirasa masih sangat kurang, karena untuk mengurus administrasi mahasiswa harus lama mengantri sehingga layanan akademik di bagian administrasi belum dapat dilakukan dengan cepat.

Demikian pula di lihat dari dimensi tangible (penampilan fisik) tempat parkir karena dapat kehujanan dan kepanasan. Begitu pula masih terdapat ruang kuliah yang belum terpenuhi LCD dan fasilitas olahraga yang belum terpenuhi dengan baik. Apalagi dengan bertambahnya jumlah mahasiswa yang tidak dibarengi dengan penambahan jumlah ruang kelas yang kurang refresentatif, menambah rendahnya dimensi tangible bagi mahasiwa.

Namun demikian, di lihat dari kuantitas mahasiswa Prodi PGSD UAD mengalami kemajuan. Mahasiswa dari tahun ketahuan mengalami penigkatan. Di awal tahun pembukaan Prodi PGSD menerima dua kelas, di tahun kedua dan ketiga menerima enam kelas. Peningkatan kuantitas harus disertai oleh peningkatan kualitas sehingga akan dapat lebih bersaing dengan kompetitor dari Prodi PGSD lainnya khususnya di wilayah DIY.
Prodi PGSD UAD sebagai prodi baru di lingkungan FKIP UAD tentu menyadari adanya keterbatasan tersebut, sehingga bagaimana tingkat kepuasan mahasiswa terhadap kualitas layanan yang diterima memerlukan penelitian dan kajian secara periodik. Menyadari akan pentingnya kualitas pelayanan dalam memberikan kepuasaan mahasiswa dan bertolak dari pemikiran tersebut, maka perlu diketahui a) bagaimana kualitas pelayanan Program Studi Pendidikan Guru Sekolah Dasar Universitas Ahmad Dahlan Yogyakarta?, b) bagaimana kepuasan mahasiswa Program Studi Pendidikan Guru Sekolah Dasar Universitas Ahmad Dahlan Yogyakarta?, dan c) apakah ada pengaruh kualitas pelayan terhadap kepuasan mahasiswa Program Studi pendidikan Guru Sekolah Dasar U niversitas Ahmad Dahlan Yogyakarta?".

\section{Metode Penelitian}

Desain penelitian yang digunakan adalah desain asosiatif kausal. Dalam penelitian ini, yang akan dianalisis adalah pengaruh kualitas pelayanan yang terdiri dari keandalan (reliability), daya tanggap (responsiveness), kepastian (assurance), ketulusan (empathy), dan bukti fisik (tangibles) terhadap kepuasan mahasiswa, dimana kualitas pelayanan merupakan variabel yang mempengaruhi (independen), 
sedangkan kepuasan mahasiswa merupakan variabel yang dipengaruhi (dependen). Populasi dalam penelitian ini adalah mahasiswa Prodi PGSD UAD Tahun Akademik 2013/2014 yang berjumlah 688 mahasiswa. Sampel penelitian diambil sebesar $25 \%$ atau sebanyak 187 mahasiswa. Pengambilan sampel diambil secara random dengan porsi $25 \%$ setiap kelas, sehingga jumlah 187 mahasiswa.

Instrumen penelitian ini meliputi angket kualitas pelayanan dan kepuasan mahasiswa. Penyusunan angket kualitas pelayanan berdasarkan pada aspek-aspek kualitas pelayanan yang dikemukakan oleh Parasuraman, Zeithaml, dan Berry (1990:24), yaitu: a) Tangibles is appearance of physical facilities equipment, personnel and communication materials; (penampilan fisik dari fasilitas, peralatan, personil dan bahan baku komunikasi), b) Reliability is ability to perform the promised service dependably and accurately; (kemampuan untuk melaksanakan pelayanan yang dijanjikan dan diberikan dengan teliti), c) Responsiveness is willingness to helpcustomers and provide prompt service; (kesediaan untuk membantu pelanggan dan menyediakan pelayanan dengan cepat), d) Assurance is knowledge and courtesy of employees and their ability to convey trust and confidence; (pengetahuan dan kemampuan untuk memberikan jaminan dan kepercayaan), dan e) Empathy is caring, individualized attention the firmprovides its customers (kepedulian, perasahaan memberikan perhatian yang berbeda kepada pelanggannya. Sedangkan mengukur tingkat kepuasan mahasiswa adalah menggunakan teori Sutardji dan Sri Ismi Maulidyah (2006: 32-37), yaitu sistem layanan yang baik, kemudahan dan kecepatan memperoleh informasi, biaya yang tidak terlalu mahal, dan lulus tepat waktu.

Teknik analisis data yang digunakan adalah analisis regresi linear berganda, karena untuk menguji pengaruh dua atau lebih variabel independent terhadap variabel dependen, yaitu pengaruh antara variable kualitas pelayanan yang terdiri dari Reliability, Responsiveness, Empathy, Assurance, dan Tangible terhadap kepuasan mahasiswa. Dengan skala pengukuran interval atau rasio dalam suatu persamaan linear, pengaruh variabel independen dalam analisis regresi linear berganda dapat diukur secara parsial dan secara bersama-sama yang ditunjukkan oleh coefficients of multiple determination $\left(\mathrm{R}^{2}\right)$. Adapun model regresi linear berganda adalah sebagai berikut:

Bentuk persamaan :

$$
\mathrm{Y}=\mathrm{a}+\mathrm{b}_{1} \mathrm{X}_{1}+\mathrm{b}_{2} \mathrm{X}_{2}+\mathrm{b}_{3} \mathrm{X}_{3}+\mathrm{b}_{4} \mathrm{X}_{4} \mathrm{~b}_{5} \mathrm{X}_{5}+\mathrm{e}
$$

Dimana:

$\mathrm{Y} \quad=$ Kinerja

a $\quad=$ Harga $Y$ bila $\mathrm{X}=0$ (Konstanta)

$\mathrm{b}=$ Koefisien regresi (terdiri dari $\mathrm{b}_{1} \mathrm{~b}_{2}$ )

$\mathrm{x}_{1} \quad=$ Reliability

$\mathrm{x}_{2} \quad=$ Responsiveness

$\mathrm{x}_{3} \quad=$ Empathy

$\mathrm{x}_{4} \quad=$ Assurance 
$\mathrm{x}_{5} \quad=$ Tangible

$\mathrm{e} \quad=$ Kesadaran pengganggu yang dalam perhitungan nilainya diasumsikan 0 (nol).

\section{Hasil dan Pembahasan}

a. Kualitas Pelayanan

Berdasarkan nilai rata-rata dan standar deviasi variabel kualitas pelayanan dapat dibuat kategori kualitas pelayanan kampus Program Studi Pendidikan Guru Sekolah Dasar UAD Tahun Akademik 2013/2014 sebagai berikut:

Tabel 1

Kategori Kualitas Pelayanan

\begin{tabular}{|c|c|c|c|}
\hline Kategori & Nilai & Jumlah & Persentase \\
\hline $\begin{array}{l}\text { Sangat } \\
\text { Baik }\end{array}$ & $\begin{array}{l}\text { Di atas } \\
68,69\end{array}$ & 25 & $13,37 \%$ \\
\hline $\begin{array}{l}\text { Cukup } \\
\text { Baik }\end{array}$ & $\begin{array}{ll}55,51 & - \\
68,69 & \\
\end{array}$ & 133 & $71,12 \%$ \\
\hline $\begin{array}{l}\text { Kurang } \\
\text { Baik }\end{array}$ & $\begin{array}{l}\text { Di } \\
\text { bawah } \\
55,51\end{array}$ & 29 & $15,51 \%$ \\
\hline \multicolumn{2}{|l|}{ Jumlah } & 187 & $100 \%$ \\
\hline
\end{tabular}

Berdasarkan tabel di atas dapat dijelaskan bahwa terdapat 25 mahasiswa atau sebesar 13,37\% menyatakan baik, 133 orang atau $71,12 \%$ menyatakan cukup, dan 29 orang atau $15,51 \%$ menyatakan kurang, sehingga dapat disimpulkan bahwa kualitas pelayanan di kampus Program Studi Pendidikan Guru Sekolah Dasar UAD berada dalam kategori cukup baik.

b. Kepuasan Mahasiswa

Berdasarkan nilai rata-rata dan standar deviasi variabel kepuasan mahasiswa dapat dibuat kategori kepuasan mahasiswa kampus Program Studi Pendidikan Guru Sekolah Dasar UAD Tahun Akademik 2013/2014 sebagai berikut:

Tabel 2

Kategori Kepuasan Mahasiswa

\begin{tabular}{|c|c|c|c|}
\hline Kategori & Nilai & Jumlah & Persentase \\
\hline $\begin{array}{l}\text { Sangat } \\
\text { Puas }\end{array}$ & $\begin{array}{l}\text { Di atas } \\
69,13\end{array}$ & 25 & $13,37 \%$ \\
\hline $\begin{array}{l}\text { Cukup } \\
\text { Puas }\end{array}$ & $\begin{array}{l}57,71- \\
69,13\end{array}$ & 134 & $71,66 \%$ \\
\hline $\begin{array}{l}\text { Kurang } \\
\text { Puas }\end{array}$ & $\begin{array}{l}\mathrm{Di} \\
\text { bawah } \\
57,71\end{array}$ & 28 & $14,97 \%$ \\
\hline \multicolumn{2}{|c|}{ Jumlah } & 187 & $100 \%$ \\
\hline
\end{tabular}

Berdasarkan tabel di atas dapat dijelaskan bahwa terdapat 25 mahasiswa atau sebesar 13,37\% menyatakan sangat puas, 134 orang atau $71,66 \%$ menyatakan cukup puas, dan 28 orang atau $14,97 \%$ menyatakan kurang puas, sehingga dapat disimpulkan bahwa kepuasan mahasiswa di kampus Program Studi Pendidikan Guru Sekolah Dasar UAD berada dalam kategori cukup puas.

\section{c. Uji Asumsi Klasik}

Selanjutnya dilakukan uji hipotesis dengan menggunakan analisis regresi ganda. Agar hasil analisis regresi akurat maka terlebih dahulu dilakukan pengujian asumsi klasik yang meliputi uji multikolinearitas, uji autokorelasi, uji heteroskedastisitas dan uji normalitas.

\section{1) Uji Multikolinearitas}

Model regresi yang baik adalah tidak terjadinya korelasi diantara variabel bebas atau tidak terjadi multikolinearitas. Model regresi yang memiliki nilai Variable Inflation Faktor (VIF) tidak lebih dari 10 dan mempunyai angka tolerance tidak 
kurang dari 0,1 berarti bebas dari multikolinearitas. Dalam penelitian ini, nilai VIF dan tolerance dapat di lihat pada tabel di bawah ini:

Tabel 3

Nilai VIF dan Angka Tolerance

\begin{tabular}{|l|c|c|}
\hline \multicolumn{1}{|c|}{ Variabel Bebas } & VIF & Tolerance \\
\hline Realibility & 1,958 & 0,511 \\
\hline Responsiveness & 2,621 & 0,382 \\
\hline Empathy & 2,458 & 0,407 \\
\hline Assurance & 1,994 & 0,502 \\
\hline Tangible & 1,585 & 0,631 \\
\hline
\end{tabular}

Berdasarkan hasil penelitian yang tercantum pada tabel nilai VIF dan angka tolerance di atas diketahui bahwa semua variabel bebas tidak lebih dari 10 dan angka tolerance tidak kurang dari 0,1 sehingga dapat disimpulkan bahwa tidak terjadinya korelasi diantara variabel bebas atau tidak terjadi multikolinearitas.

\section{2) Uji Autokorelasi}

Model regresi yang bebas dari autokorelasi dapat dilihat dari nilai DurbinWatson yang diinterpretasikan sebagai berikut:

$<1,10$ adalah ada autokorelasi

1,10 - 1,54 adalah tidak ada kesimpulan

1,55 - 2,46 adalah tidak ada autokorelasi

2,46 - 2,90 adalah tidak ada kesimpulan

$>$ 2,91 adalah ada autokorelasi

Hasil penelitian ini menunjukkan nilai Durbin-Watson sebesar 1,587. Oleh karena itu dapat disimpulkan bahwa tidak ada autokorelasi.

\section{3) Uji Heteroskedastisitas}

Model regresi yang bebas dari heteroskedastisitas dapat dilihat dari ada tidaknya pola tertentu pada grafik scatter plot serta titik-titik yang menyebar diatas dan dibawah angka 0 pada sumbu Y. Jika titik-titik pada scatter plot membentuk suatu pola tertentu yang teratur (bergelombang, melebar, atau menyempit) maka terjadi heteroskedastisitas. Hasil dari grafik scatter plot dalam penelitian ini dapat dilihat pada grafik di bawah ini:

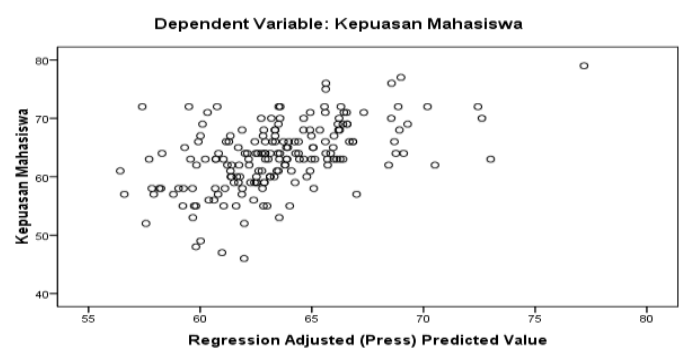

Gambar 1

Scatter Plot Kepuasan Mahasiswa

Berdasarkan grafik scatter plot dapat dilihat bahwa titik-titik menyebar dan tidak membentuk suatu pola tertentu sehingga dapat dikatakan bahwa tidak terjadi heteroskedastisitas.

\section{4) Uji Normalitas}

Normalitas data dapat dilihat melalui sebaran titik-titik residual yang berada di sekitar garis normal dari grafik Normality Probability Plot. Hasil normalitas data ini dapat di lihat pada grafik berikut:

Normal P-P Plot of Regression Standardized Residual

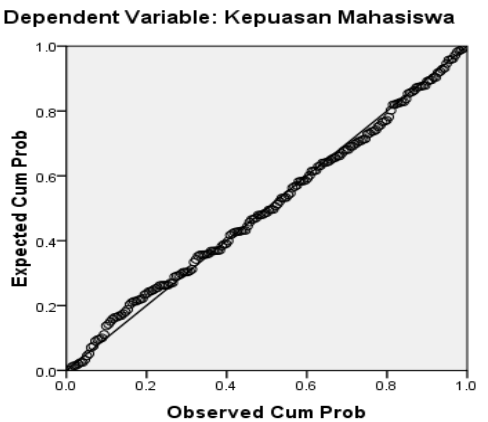




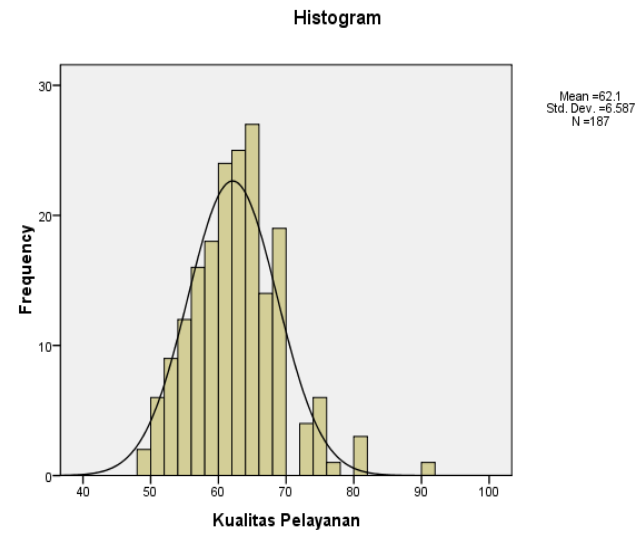

Gambar 2

Grafik Normal Plot Kepuasan Mahasiswa

Berdasarkan grafik normality probability sebaran titik-titik residual berada di sekitar garis normal sehingga asumsi normalitas terpenuhi.

\section{d. Analisis Regresi Berganda}

Setelah semua asumsi klasik terpenuhi maka dapat dilakukan analisis regresi linear berganda. Model analisis regresi berganda digunakan untuk mengetahui pengaruh kualitas pelayanan (Reliability, Responsiveness, Emphaty, Assurance dan Tangible) terhadap kepuasan mahasiswa. Rangkuman hasil analisis dapat di lihat pada tabel berikut ini:

Tabel 4

Rangkuman Hasil Uji Regresi Berganda

\begin{tabular}{|l|c|c|}
\hline \multirow{2}{*}{ Model } & \multicolumn{2}{|c|}{$\begin{array}{c}\text { Unstandardized } \\
\text { Coefficient }\end{array}$} \\
\cline { 2 - 3 } & B & Std. Error \\
\hline Konstan & 34,079 & 3,383 \\
\hline Reliability & 0,335 & 0,300 \\
\hline Responsiveness & 0,057 & 0,320 \\
\hline Emphaty & 0,663 & 0,395 \\
\hline Assurance & 0,800 & 0,338 \\
\hline Tangible & 0,607 & 0,223 \\
\hline
\end{tabular}

Berdasarkan tabel hasil rangkuman analisis data diatas dapat disusun persamaan regresi sebagai berikut:

$Y=34,079+0,335 X_{1}+0,057 X_{2}+0,663 X_{3}+0,800 X_{4}+0,607 X_{5}$

Dari persamaan regresi di atas dapat dinyatakan bahwa konstantanya sebesar 34,079 , sedangkan nilai koefisien regresi $\mathrm{X}_{1}$ sebesar 0,335, nilai koefisien regresi $X_{2}$ sebesar 0,057, nilai koefisien regresi $\mathrm{X}_{3}$ sebesar 0,663, nilai koefisien regresi $\mathrm{X}_{4}$ sebesar 0,800 dan nilai koefisien regresi $\mathrm{X}_{5}$ sebesar 0,607. Sedangkan nilai R Square (determinasi berganda) yang ditunjukkan pada lampiran sebesar 0,314 atau 31,4\%.

Berdasarkan persamaan regresi tersebut di atas, maka dapat dijelaskan sebagai berikut:

1) Nilai konstanta sebesar 34,079 menunjukkan bahwa jika tidak dipengaruhi oleh variabel reliability, responsiveness, emphaty, Assurance, dan tangible maka dimensi kepuasan mahasiswa sebesar 34,079.

2) Nilai koefisien variabel $X_{1}$ (reliability) sebesar 0,355 menunjukkan bahwa jika dimensi reliability bertambah satu satuan maka kepuasan mahasiswa akan naik sebesar 0,355 dengan asumsi dimensi responsiveness, emphaty, Assurance, dan tangible ceteris paribus.

3) Nilai koefisien variabel $\quad X_{2}$ (responsiveness) $\quad$ sebesar $\quad 0,057$ menunjukkan bahwa jika dimensi responsiveness bertambah satu satuan 
maka kepuasan mahasiswa akan naik sebesar 0,057 dengan asumsi dimensi reliability, emphaty, Assurance, dan tangible ceteris paribus.

4) Nilai koefisien variabel $X_{3}$ (emphaty) sebesar 0,663 menunjukkan bahwa jika dimensi emphaty bertambah satu satuan maka kepuasan mahasiswa akan naik sebesar 0,663 dengan asumsi dimensi reliability, responsiveness, Assurance, dan tangible ceteris paribus.

5) Nilai koefisien variabel $X_{4}$ (assurance) sebesar 0,800 menunjukkan bahwa jika dimensi assurance bertambah satu satuan maka kepuasan mahasiswa akan naik sebesar 0,800 dengan asumsi dimensi reliability, responsiveness, emphaty, dan tangible ceteris paribus.

6) Nilai koefisien variabel $\mathrm{X}_{5}$ (tangible) sebesar 0,607 menunjukkan bahwa jika dimensi tangible bertambah satu satuan maka kepuasan mahasiswa akan naik sebesar 0,607 dengan asumsi dimensi reliability, responsiveness, emphaty, dan Assurance ceteris paribus.

7) Nilai R Square (determinasi berganda) sebesar 0,314 atau $31,4 \%$ berarti variabel bebas (reliability, responsiveness, emphaty, Assurance, dan tangible) secara simultan berpengaruh atau berperan sebesar $31,4 \%$ terhadap kepuasan pelanggan, sedangkan sisanya sebesar $68,6 \%$ merupakan kontribusi variabelvariabel lainnya yang tidak dimasukkan dalam penelitian ini, seperti kepemimpinan dan manajemen lembaga.

Tabel 5

Rangkuman Koefisien Korelasi

\begin{tabular}{|l|c|c|}
\hline \multicolumn{1}{|c|}{ Model } & $\mathbf{r}$ & $\mathbf{r}^{2}$ \\
\hline Reliability & 0,069 & 0,005 \\
\hline Responsiveness & 0,011 & 0,001 \\
\hline Emphaty & 0,103 & 0,011 \\
\hline Assurance & 0,146 & 0,021 \\
\hline Tangible & 0,523 & 0,273 \\
\hline
\end{tabular}

Berdasarkan tabel di atas diketahui nilai koefisien korelasi variabel reliability dengan kepuasan mahasiswa sebesar 0,069 sehingga $r^{2}=0,005$, nilai koefisien korelasi variabel responsiveness dengan kepuasan mahasiswa sebesar 0,011 sehingga $r^{2}=$ 0,001, nilai koefisien korelasi variabel emphaty dengan kepuasan mahasiswa sebesar 0,103 sehingga $r^{2}=0,011$, nilai koefisien korelasi variabel Assurance dengan kepuasan mahasiswa sebesar 0,146 sehingga $\mathrm{r}^{2}=0,021$, dan nilai koefisien korelasi variabel tangible dengan kepuasan mahasiswa sebesar 0,523 sehingga $r^{2}=$ 0,273 .

\section{e. Uji Hipotesis}

Di dadalam penelitian ini, uji $t$ digunakan untuk mengetahui pengaruh secara parsial masing-masing variabel bebas kualitas pelayanan yang terdiri dari reliability, responsiveness, emphaty, Assurance, dan tangible terhadap kepuasan mahasiswa Prodi PGSD UAD terhdapa variabel kepuasan mahasiswa. Uji hipotesis dilakukan dengan melihat analisis uji $-\mathrm{t}$, yaitu dengan membandingkan tingkat 
signifikansi masing-masing variabel bebas dengan taraf nyata 5\%. Jika sig.t $<5 \%$ maka Ho ditolak dan Ha diterima. Rangkuman hasil uji - $\mathrm{t}$ dapat dilihat pada tabel berikut:

Tabel 6 Rangkuman Hasil Uji - t

\begin{tabular}{|l|c|c|}
\hline \multicolumn{1}{|c|}{ Model } & $\mathbf{t}_{\text {hitung }}$ & Sig. \\
\hline Reliability & 1,114 & 0,267 \\
\hline Responsiveness & 0,177 & 0,860 \\
\hline Emphaty & 1,678 & 0,095 \\
\hline Assurance & 2,366 & 0,019 \\
\hline Tangible & 2,718 & 0,007 \\
\hline
\end{tabular}

Berdasarkan tabel di atas nilai $\mathrm{t}_{\text {hitung }}$ variabel reliability 1,114 dengan taraf signifikansi 0,267 , nilai $t_{\text {hitung }}$ variabel responsiveness 0,177 dengan taraf signifikansi 0,860 , nilai $t_{\text {hitung }}$ variabel emphaty 1,678 dengan taraf signifikansi 0,095, nilai $t_{\text {hitung variabel assurance 2,366 }}$ dengan taraf signifikansi 0,019 dan nilai $\mathrm{t}_{\text {hitung }}$ variabel tangible 2,718 dengan taraf signifikansi 0,007 .

\section{f. Pembahasan}

Berdasarkan hasil penelitian ini dapat diketahui bahwa hanya variabel tangible dan assurance saja yang mempunyai pengaruh signifikan terhadap kepuasan mahasiswa Program Studi pendidikan guru Sekolah Dasar Universitas Ahmad Dahlan Yogyakarta. Dimensi tangible memberikan pengaruh yang paling dominan terhadap kepuasan mahasiswa Program Studi pendidikan guru Sekolah Dasar Universitas Ahmad Dahlan Yogyakarta, yaitu sebesar 27,3\%, dimensi assurance memberikan pengaruh sebesar 2,13\%, dimensi emphaty memberikan pengaruh sebesar 1,06, dimensi reliability memberikan pengaruh sebesar $0,48 \%$ dan dimensi responsiveness memberikan pengaruh sebesar 0,01\%. Sedangkan secara simultan dimensi reliability, responsiveness, emphaty, assurance, dan tangible berpengaruh atau berperan sebesar $31,4 \%$ terhadap kepuasan pelanggan, sedangkan sisanya sebesar $68,6 \%$ merupakan kontribusi variabel-variabel lainnya yang tidak dimasukkan dalam penelitian ini.

Hasil penelitian ini mendukung penelitian Tutik Wahyuningsih, Sunarto, dan Leny Noviani (2013). Penelitian yang berjudul Kepuasan Mahasiswa FKIP UNS atas Kualitas Pelayanan Administrasi Akademik. Hasil penelitian ini menyimpulkan bahwa variabel kualitas layanan yang meliputi bukti langsung, keandalan, daya tanggap, jaminan dan empati memiliki pengaruh secara simultan dan parsial terhadap kepuasan mahasiswa. Bahkan $72 \%$ kepuasan mahasiswa dipengaruhi oleh bukti langsung, keandalan, daya tanggap, jaminan dan empati.

Temuan dalam penelitian ini juga memperkuat penelitian yang telah dilakukan oleh Zurni Zahara Samosir (2005). Penelitian yang berjudul Pengaruh Kualitas Pelayanan terhadap Kepuasan Mahasiswa Menggunakan Perpustakaan USU. Hasil 
penelitian dilaporkan kualitas pelayanan (kehandalan, daya tanggap, jaminan, empati, dan bukti langsung) secara serempak berpengaruh signifikan terhadap kepuasan mahasiswa yang berarti dimensi kualitas pelayanan beserta indikator-indikatornya memberikan pengaruh nyata terhadap kepuasan mahasiswa dalam menggunakan perpustakaan USU. Secara parsial, dimensi tangible merupakan dimensi kualitas pelayanan yang paling mempengaruhi kepuasan mahasiswa dalam menggunakan perpustakaan di USU.

Hasil penelitian ini menunjukkan bahwa kepuasan mahasiswa sangat kuat dipengaruhi oleh kemampuan lembaga dalam melayani dan memberikan yang terbaik pada dimensi tangible dan assurance. Dimensi tangible merupakan faktor pendorong awal seseorang dalam menilai kualitas pelayanan, karena lebih mudah melihat fisik dari pada pelayanan yang lainnya. Dimensi tangible memberikan andil yang paling besar terhadap kepuasan mahasiswa. Hasil penelitian ini mendukung pula penelitian I Nyoman Rinala, I Made Yudana, dan I Nyoman Natajaya (2013) dengan judul penelitiannya Pengaruh Kualitas Pelayanan Akademik Terhadap Kepuasan dan Loyalitas Mahasiswa Pada Sekolah Tinggi Pariwisata Nusa Dua Bali. Hasil penelitian tersebut membuktikan bahwa bukti fisik (tangibles) memberikan efek langsung terhadap kepuasan mahasiswa sebesar $92,8 \%$. Ini berarti bahwa fasilitas fisik yang disediakan untuk mendukung proses pembelajaran di STP Nusa Dua Bali sangat baik. Fasilitas fisik seperti ruang kelas, lab prktikum beserta peralatan pembelajaran yang lengkap dan modern sangat penting untuk menciptakan kualitas pelayanana akademik. Penampilan dosen/pengajar dan staf administrasi yang rapi serta tersedianya tempat parkir, fasilitas ekstra kurikuler dan perpustakaan dengan buku atau bahan ajar sesuai kurikulum pembelajaran mahasiswa, juga sebagai aspek penentu kualitas pelayanan di bidang akademik di STP Nusa Dua Bali.

Oleh karena itu, dari hasil penelitian ini dihararapkan bisa mendorong pimpinan perguruan tinggi untuk lebih perhatian pada pelayanan yang menyangkut fasilitas fisik/perlengkapan, penampilan karyawan dan sarana komunikasi. Misalnya keindahan interior kantor, kebersihan dan kelengkapan kantor, kerapian penampilan karyawan, keserasian tata letak kantor, kemudahan dan keamanan tempat parkir, serta kelengkapan sarana telekomunikasi.

Pihak Program Studi Pendidikan Guru Sekolah Dasar Universitas Ahmad Dahlan Yogyakarta perlu memperbaiki peralatan dan perlengkapan layanan, peningkatan kondisi penampilan fisik ruangan pelayanan administrasi akademik, penampilan dosen dan karyawan yang rapi, 
memberikan pelatihan soft skill agar dosen dan karyawan dapat memberikan pelayanan yang lebih baik, selalu siap dalam membantu mahasiswa, bersikap ramah dan sopan dalam memberikan pelayanan akademik, serta mampu berkomunikasi baik dengan mahasiswa.

Demikian pula pada dimensi assurance (pengetahuan dan kemampuan untuk memberikan jaminan dan kepercayaan) juga menunjukkan pengaruh yang signifikan terhadap kepuasan mahasiswa. Hal ini mendukung hasil penelitian dari M. Arief, A. Yahya Suryadinata (2010) yang menyatakan jaminan merupakan dimensi kualitas pelayanan yang kurang signifikan dalam mengukur kepuasan pelanggan atas pelayanan di universitas Trunojoyo. Penelitian lain Dwi Aryani, Febrina Rosita (2010), Skogland and Siguaw, J, A. (2004), menyatakan assurance merupakan faktor kualitas pelayanan pada bidang jasa pendidikan (I Nyoman Rinala, I Made Yudana, dan I Nyoman Natajaya, 2013:10).

Dimensi atau faktor jaminan (assurance) merupakan faktor kualitas pelayanan yang signifikan mempengaruhi kepuasan mahasiswa. Artinya, kemampuan dosen dan karyawan untuk memberikan keyakinan kepada mahasiswa bahwa jasa/layanan yang diberikannya telah sesuai dengan ketentuan atau harapan mahasiswa menjadi hal yang penting dalam memenuhi kepuasan mahasiswa. Perilaku dosen dan karyawan mampu menumbuhkan kepercayaan pelanggan terhadap lembaga dan lembaga bisa menciptakan rasa aman bagi mahasiswa, sehingga menuntut dosen dan karyawan untuk bersikap sopan dan menguasai pengetahuan dan keterampilan yang dibutuhkan untuk menangani setiap pertanyaan atau masalah mahasiswa.

Hal demikian itu sangat penting untuk dilakukan mengingat persaingan di dunia pendidikan tinggi sudah semakin tajam. Memberikan pelayanan yang baik kepada mahasiswa menjadi hal yang utama yang dapat mendorong terciptanya lingkungan akademis yang kondusif, sehingga tujuan pembelajara di pendidikan tinggi dapat dicapai. Pelayanan yang baik di dalam perguruan tinggi dapat menjadi sarana pemasaran internal, yaitu mutu pelayanan prima yang telah diterima mahasiswa akan disampaikan kepada orang lain atau kepada pihak luar perguruan tinggi sehingga akan lebih mendapatkan kepercayaan masyarakat dan memberi peluang menambah daya saing serta memperoleh mahasiswa baru semakin besar. Tentunya hal ini perlu mendapat perhatian dari Program Studi Pendidikan Guru Sekolah Dasar Universitas Ahmad Dahlan Yogyakarta untuk terus menerus meningkatkan kualitas pelayanannya.

Kendatipun hasil penelitian ini 
membuktikan dimensi tangible, dan assurance merupakan faktor yang memberikan efek kuat, dan reliability, responsiveness dan empathy memberikan efek lemah, namun pihak lembaga tidak mengabaikan perhatian terhadap dimensi lainnya walaupun variabel reliability, responsiveness dan emphaty tidak mempunyai pengaruh signifikan terhadap kepuasan mahasiswa Program Studi Pendidikan Guru Sekolah Dasar Universitas Ahmad Dahlan Yogyakarta. Ketiga dimensi tersebut bilamana ditingkatkan kualitas pelayanannya juga dapat memberikan pengaruhi terhadap kepuasan mahasiswa, karena secara simultan atau bersama-sama kelima dimensi kualitas pelayanan memberikan pengaruh positif yang signifikan terhadap kepuasan mahasiswa Program Studi pendidikan guru Sekolah Dasar Universitas Ahmad Dahlan Yogyakarta. Oleh karena itu, untuk meningkatkan kepuasan mahasiswa maka secara bersamaan pula meningkatkan kualitas pelayanan, karena tanggapan mahasiswa terhadap kualitas pelayanan itu sendiri merupakan penilaian holistik terhadap keunggulan pelayanan yang diberikan lembaga.

\section{Kesimpulan dan Saran}

Berdasarkan hasil penelitian dan pembahasan di atas dapat ditarik kesimpulan sebagau berikut: a. Kualitas pelayanan Prodi PGSD UAD tergolong cukup baik

b. Mahasiswa merasa cukup puas dengan pelayanan yang diberikan oleh Prodi PGSD UAD.

c. Terdapat dua dimensi yang mempunyai pengaruh signifikan terhadap kepuasan mahasiswa Program Studi pendidikan guru Sekolah Dasar Universitas Ahmad Dahlan Yogyakarta, dari lima dimensi kualitas pelayanan yaitu dimensi tangible dan dimensi assurance, sedangkan dimensi reliability, responsiveness dan dimensi emphaty tidak mempunyai pengaruh signifikan terhadap kepuasan mahasiswa Program Studi pendidikan guru Sekolah Dasar Universitas Ahmad Dahlan Yogyakarta. Namun demikian, secara simultan dimensi kualitas memberikan pengaruh yang signifikan terhadap kepuasan mahasiswa Program Studi pendidikan guru Sekolah Dasar Universitas Ahmad Dahlan Yogyakarta.

Berdasarkan kesimpulan di atas maka dapat diajukan beberapa saran sebagai berikut:

a. Disarankan Prodi PGSD UAD perlu menekankan perhatiannya terhadap dimensi tangible atau layanan yang menyangkut fasilitas fisik/perlengkapan, penampilan karyawan dan sarana komunikasi, karena dimensi ini pengaruhnya paling kuat terhadap kepuasan mahasiswa. Demikian 
pula pada dimensi assurance, hendaknya para dosen dan karyawan lebih meningkatkan pengetahuan dan kemampuan untuk memberikan jaminan dan kepercayaan terhadap mahasiswa.

b. Disarankan juga pada Prodi PGSD UAD hendaknya tidaka mengabaikan perhatiannya terhadap dimensi lainnya (reliability, responsiveness dan dimensi emphaty), karena dimensi tersebut secara simultan juga memberikan pengaruh pada kepuasan mahasiswa.

\section{DAFTAR PUSTAKA}

I Nyoman Rinala, I Made Yudana, dan I Nyoman Natajaya. 2013. Pengaruh Kualitas Pelayanan Akademik Terhadap Kepuasan dan Loyalitas Mahasiswa Pada Sekolah Tinggi Pariwisata Nusa Dua Bali. e-Journal Program Pascasarjana Universitas Pendidikan Ganesha Program Studi
Administrasi Pendidikan, Volume 4 Tahun 2013.

Parasuraman, A., Zeithaml, V. A., \& Berry, L. L. 1985. A Conceptual Model of Service Quality and Its Implications for Future Research. Journal of Marketing, Vol.49, 41-50.

Parasuraman, A., Zeithaml, V. A., \& Berry, L. 1988. SERVQUAL: A Multiple-Item Scale for Measuring Consumer Perceptions of Service Quality. Journal of Retailing, Vol.64 No. 1, 12-40.

Tjiptono, Fandy. 2004. Manajemen Jasa. Yogyakarta: Andi Offset.

Tjiptono, Fandy. 1997. Strategi Pemasaran. Yogyakarta: Andi Offset

Wadwa, Raja. 2006. School Organization. Journal Of Education. Vol 72.

Zurni Zahara Samosir. 2005. Pengaruh Kualitas Pelayanan terhadap Kepuasan Mahasiswa Menggunakan Perpustakaan USU. Jurnal Studi Perpustakaan dan Informasi, Vol. 1, No. 1, Juni 2005. 